\title{
Evaluation of oxidative stability of new cold-pressed sunflower oils during accelerated thermal stability tests
}

\author{
Tanja Z. LUŽAIĆ ${ }^{1}$, Nada L. GRAHOVAC ${ }^{2}$, Nada T. HLADNI², Ranko S. ROMANIĆ ${ }^{1 \star}$
}

\begin{abstract}
Refined sunflower oil has dissimilar shelf life compared to cold-pressed sunflower oil, which increases the use of refined oil, and it is more abundant in the diet. On the other hand, the production of cold-pressed oils does not require chemical processing. Moreover, these oils contain significant amounts of bioactive components with a beneficial health effect. Breeders are trying to create new sunflower hybrids for the production of cold-pressed oil with improved oxidative characteristics. This study aims to examine the rancidity of 24 cold-pressed sunflower oils of new hybrids under accelerated thermal stability test conditions (Rancimat and Schaal oven tests) and to compare the obtained results with refined sunflower oil. According to investigated oxidative parameters, the most similar to refined sunflower oil was the $\mathrm{H} 20$ sample with the induction period determined by the Rancimat test of $9.55 \pm 0.00 \mathrm{~h}$, compared to $9.49 \pm 0.00 \mathrm{~h}$, obtained in refined sunflower oil. The total oxidation value of the $\mathrm{H} 20$ sample amounted to $3.26 \pm 0.12$, while in refined sunflower oil this value was $2.12 \pm 1.73$.
\end{abstract}

Practical Application: The study will be useful to oil producers in choice of hybrids for the oil production.

Keywords: sunflower oil, schaal oven test, rancimat test, iodine value, principal component analysis.

\section{Introduction}

The quality and potential uses of vegetable oils are determined by their fatty acid composition (Akkaya, 2018). Sunflower oil is one of the most abundant vegetable oils because of its nutritive and industrial attributes. Refined sunflower oil is mostly present in the population diet due to dissimilar shelf life compared to cold-pressed oil, which is an even greater challenge for breeders trying to create hybrids with improved oxidative characteristics. Today there are different types of hybrids from the aspect of fatty acid composition: standard sunflower oil (linoleic type), mid oleic sunflower oil, high oleic, high stearic, high stearic high oleic, high palmitic and high palmitic high oleic sunflower oil (Salas et al., 2015; Serrano-Vega et al., 2005, Salas et al., 2011). Standard sunflower oil is rich in linoleic fatty acid, with a content of 48 to $74 \%$. It contains small amounts of saturated fatty acids, mainly palmitic and stearic, and unlike other oils such as soybean and rapeseed, sunflower oil contains negligible amounts of linolenic acid. The presence of long-chain fatty acids, such as arachidonic and behenic, is also significant (Codex Committee on Fats and Oils, 2005; Salas et al., 2015).

Oxidative stability is one of the most important parameters used to assess the quality of oil, determining its resistance to the oxidation process (Symoniuk et al., 2018). Oxidation occurs with unsaturated fatty acids, during oil storage or heat treatment and causes their deterioration (Ferrari \& Souza, 2009). Oils with a high content of polyunsaturated fatty acids, especially linolenic acid, oxidize rapidly. In addition to triacylglycerols, oils obtained by cold-pressing also contain lipid-accompanying compounds.
Therefore, its stability depends not only on the composition of fatty acids but also on the content of antioxidants, primary and secondary oxidation products, metals and other contaminants that can accelerate or inhibit the oxidation process (Choe \& Min, 2006; Górnaś et al., 2014; Szterk et al., 2010; Landers \& Rathmann, 1981; Ferrari \& Souza, 2009; de Lira et al., 2010).

Lipid oxidation takes place through a set of autocatalytic reactions that produce a high number of new compounds. Hydroperoxides, the primary oxidation compounds, decompose giving rise to a variety of secondary oxidation products (Marmesat et al., 2009). The primary oxidation compounds analysis is always carried out by the peroxide value (PV), or, by the determination of conjugated dienes content $(\mathrm{CD})$, since the hydro peroxides of polyunsaturated fatty acids, the most susceptible fatty acids to undergo oxidation, have a strong absorbance at $232 \mathrm{~nm}$ (Dobarganes \& Velasco, 2002; Marmesat et al., 2009). While the absorbance at $270 \mathrm{~nm}$, as determined by the content of conjugated trienes (CT), have only oxidation products of some fatty acids such as gamma-linolenic, arachidonic, eicosapentaenoic, docosahexaenoic (Takagi et al., 1987). Hydroperoxides decompose at higher temperatures to form volatile and non-volatile components such as dimers, trimers, polymers, alcohols and other secondary oxidation products that also significantly affect the oxidative stability of the oil. In order to monitor the rancidity of oil, the $p$-anisidine value ( $p-\mathrm{AnV})$ and the total oxidation value (totox) are being determined (Saeed \& $\mathrm{Naz}, 2019)$. The $p$-anisidine value indicates secondary oxidation products (Leong et al., 2015; Patsioura et al., 2017). 
This study aims to investigate the oxidative stability of new 24 cold-pressed sunflower oils in accelerated stability test conditions. The difference in the degree of unsaturation of fatty acids was shown by the iodine value, and two accelerated thermal stability tests, Rancimat and Schaal oven were applied. The tested samples were compared with refined sunflower oil due to its presence in the diet and consumer habits. One of the goals in the selection of new sunflower hybrids is to improve the oxidative stability of the oil. Furthermore, the main goal of the paper is the application of principal component analysis (PCA) to perform mapping of the samples by their oxidative characteristics. Mapping isolated samples similar to refined sunflower oil will help oil producers in the choice of a new sunflower hybrid.

\section{Material and methods}

\subsection{Cold pressed oils production}

Sunflower hybrid seeds were produced by the Institute of Field and Vegetable Crops, Novi Sad and grown on its experimental fields in Vojvodina (Serbia) (between $45^{\circ} 46^{\prime} 27^{\prime \prime} \mathrm{N}, 19^{\circ} 6^{\prime} 44^{\prime \prime} \mathrm{E}$ and $44^{\circ} 52^{\prime} 14^{\prime \prime} \mathrm{N}, 20^{\circ} 38^{\prime} 25^{\prime \prime} \mathrm{E}$, year: 2017). Twenty-four sunflower hybrids (confectionary hybrids (H1-H18), oily hybrids with high oil content (H19, H22, H23, H24) and oily hybrids with altered fatty acid composition (H20, H21)) were investigated. Sunflower hybrids were grown under standard cultivation conditions without irrigation. Hybrids were sown in a randomized complete-block design with three replications. Collected seeds of individual hybrid were mixed. Five $\mathrm{kg}$ of seed of each hybrid were stored at $20^{\circ} \mathrm{C}$ for 6 months and pressed. After storage seeds were pressed at a screw press of the designed capacity $25-30 \mathrm{~kg} \mathrm{~h}^{-1}$, run by a frequency of $27.5 \mathrm{~Hz}$ and real capacity between 15 and $30 \mathrm{~kg}$ $\mathrm{h}^{-1}$. At the output of the press, two products, oil and cake, were obtained. The temperature of sunflower oil (at output of press) was between 40 and $60^{\circ} \mathrm{C}$. Differences in the oil temperature, as well as in a capacity were a direct consequence of different seed characteristics of the investigated samples. Obtained cold pressed oils were filtered through filter paper into $500 \mathrm{~mL}$ PET bottles, filled with no empty space, sealed and stored at refrigerator at $6 \pm 1^{\circ} \mathrm{C}$ until tested.

The RSO (refined high oleic sunflower oil) sample was a commercially available sample purchased in a store on the market. This sample does not contain added antioxidants.

\subsection{Iodine value determination}

Iodine value, IV, was determined according to ISO 3961:2018 (International Organization for Standardization, 2018). A portion of the oil sample (0.13-0.15g) was weighed to the nearest $0.0001 \mathrm{~g}$, added to a $500 \mathrm{~mL}$ Erlenmeyer flask, and dissolved using $20 \mathrm{~mL}$ of solvent (prepared by mixing equal volumes of cyclohexane and glacial acetic acid) and $25 \mathrm{~mL}$ of Wijs solution. This solution was allowed to rest for $1 \mathrm{~h}$ in the dark with a blank prepared in the same manner except that it did not contain any sample. Then, $20 \mathrm{~mL}$ of a potassium iodide solution $(100 \mathrm{~g}$ $\left.\mathrm{L}^{-1}\right)$ and $150 \mathrm{~mL}$ of distilled water was added. Titration with a standardized $0.1 \mathrm{~mol} \mathrm{~L}^{-1}$ sodium thiosulfate solution using an automatic burette was carried out until the solution was a pale yellow color. Then, $3 \mathrm{~mL}$ of a starch solution was added. The titration was continued until the blue color disappeared. All reagents were of analytical grade.

\subsection{Accelerated stability tests}

Rancimat accelerated stability test was made on Metrohm Rancimat model 743 (Herisau, Switzerland) to measure the induction period of oil samples. Measurements were done according to ISO 6886:2016 (International Organization for Standardization, 2016b). The oil sample of $2.5 \pm 0.01 \mathrm{~g}$ was oxidized with a heating temperature of $110{ }^{\circ} \mathrm{C}$ and the airflow of 18-20 L h $\mathrm{h}^{-1}$. Volatile products formed from oxidation reaction were solubled in $0.05 \mathrm{~L}$ of distilled water. The induction period, IP, was recorded automatically by apparatus software with an accuracy of 0.1 , and the result was expressed in hours.

Schaal oven accelerated stability test was performed. For this test $50 \mathrm{~mL}$ of each sample twice in glass vessels of internal diameter $88 \mathrm{~mm}$ and height $18 \mathrm{~mm}$ was measured and subjected to test conditions: at moderate temperatures $\left(63 \pm 2{ }^{\circ} \mathrm{C}\right)$, in the presence of air, without the presence of light according to the methodology described by Gomes et al. (2010), Maszewska et al. (2018), and Naderi et al. (2018) for a period of 4 and 8 days. In the initial samples ( $0^{\text {th }}$ day of the test $), 4^{\text {th }}$, and $8^{\text {th }}$ day of the test peroxide value, $\mathrm{PV}, p$-anisidine value, $p$ - $\mathrm{AnV}$, total oxidation value, TOTOX, conjugated dienes, $\mathrm{CD}$, and conjugated trienes content, $\mathrm{CT}$, were investigated. The PV and $p$-AnV were determined according to ISO 3960:2007 (International Organization for Standardization, 2017b) and ISO 6885:2016 (International Organization for Standardization, 2016a), respectively. The TOTOX was calculated according to Oomah et al. (2000). CD and CT, coefficients of specific extinction at the absorption wavelengths of $232 \mathrm{~nm}$ and $270 \mathrm{~nm}$, were determined according to method ISO 3656:2013/Amd 1:2017 (International Organization for Standardization, 2017a). All spectrophotometric measurements were made at a UV/VIS spectrophotometer model T80+ (PG Instruments Limited, London).

\subsection{Statistical analysis}

All results are presented as a mean value \pm standard deviation $(\mathrm{n}=3)$. One way analysis of variance (ANOVA) with a Tukey test was used to determine significant differences among the data at the significance level $p<0.05$. The degree of a linear relationship between two variables was measured using Pearson's correlation coefficient and significant correlations were at the significance level $p<0.01$ and $p<0.001$. Statistical processing of the obtained results was performed Statistica version 20 (StatSoft, Tulsa, Oklahoma, USA).

The PCA is a statistical analysis used to reduce the initial amount of data to obtain orthogonal variables (GonzálezDíaz et al., 2007). The results of the PCA of 25 samples based on oxidative characteristics (PV, p-AnV, CD, CT, TOTOX) during the Schaal oven test (initial samples, after 4 and 8 days of the test), IP obtained by Rancimat test and IV of oils are presented in the form of scores and loadings plots. Scores are new coordinates of projected objects and loadings that reflect the direction taking into account the original variables (Kovačević et al., 2013). 


\section{Results and discussion}

\subsection{Iodine value and oxidative stability - Rancimat test}

The degree of unsaturation, expressed as IV is an important factor in oil quality. In the examined samples the lowest IV was $81 \pm 2.04 \mathrm{gI}_{2} 100^{-1} \mathrm{~g}^{-1}$ (sample H21) while the highest value was $127 \pm 5.38 \mathrm{gI}_{2} 100^{-1} \mathrm{~g}^{-1}$ (sample H19). No significant difference $(\mathrm{p}<0.05)$ was found between the IV of samples $\mathrm{H} 21$ and RSO. The IV of the other samples were significantly higher (Figure 1a). The obtained results were in line with the previous studies. Naimly, Popescu et al. (2015) examined the IV of 8 sunflower oil samples and obtained an average value of $116.99 \pm 1.56 \mathrm{gI}_{2} 100^{-1} \mathrm{~g}^{-1}$. Konuskan et al. (2019) reported similar IV found in sunflower oil $\left(102 \mathrm{gI}_{2} 100^{-1} \mathrm{~g}^{-1}\right)$. RSO and H21 samples had IV similar to olive oil (75.43 $\pm 1.35 \mathrm{gI}_{2} 100^{-1}$ $\mathrm{g}^{-1}$ reported by Popescu et al. (2015) which probably indicates a higher content of oleic fatty acid in their composition, i.e. oleic sunflower hybrids were used in the oil production. H20 sample had an IV slightly higher compared to previous two samples but still lower than the other tested oils. The IV $\left(101 \pm 2.53 \mathrm{gI}_{2}\right.$ $100^{-1} \mathrm{~g}^{-1}$ ) determinated in this sample probably indicate lower oleic fatty acids content compared to H21 sample, but still higher compared to the remaining oil samples.

The direct influence of the IV on the oxidative stability is visible in Figure 1b, showing the IP values obtained in examined samples by the Rancimat accelerated stability test. A significant $(p<0.001)$ negative correlation between the IV and the IP values $(-0.96)$ in tested samples was found. Previous studies have also confirmed the negative correlation of these parameters (Górnaś et al., 2017; Hashemi et al., 2015). The IP values obtained in the tested samples ranged from $3.32 \pm 0.00 \mathrm{~h}(\mathrm{H} 19)$ to $9.55 \pm 0.00 \mathrm{~h}(\mathrm{H} 21)$, consistent with the obtained IV extreme values. Symoniuk et al. (2018) reported higher IP values obtained in two cold-pressed sunflower oils $(6.42 \pm 0.06 \mathrm{~h}$ and $19.87 \pm 0.07 \mathrm{~h})$, determined at same flow rate conditions $\left(20 \mathrm{~L} \mathrm{~h}^{-1}\right)$ but lower temperature $\left(100{ }^{\circ} \mathrm{C}\right)$. So high difference in the IP values obtained was a consequence of the differences in the fatty acid composition of these two samples. Namely, oil sample with a lower IP contained $66.02 \%$ linoleic and $18.52 \%$ oleic fatty acid, while another sample contained $5.49 \%$ linoleic and $86.52 \%$ oleic fatty acid. Based on reported fatty acid composition, a higher degree of unsaturation (ie a higher IV) had the first sample compared to the second one. Oils containing unsaturated fatty acids are highly susceptible to oxidation (Choe \& Min, 2006).

\subsection{Oxidative stability - Schaal oven test}

Oxidative stability is an important oil safety factor used to estimate its susceptibility to oxidation and its shelf life consequently (Symoniuk et al., 2018). In the Schaal oven test conditions, a significant increase $(p<0.05)$ in PV and TOTOX was noticed in all samples except the control sample (RSO), there was no significant increase on $4^{\text {th }}$ day of the test. After 8 days, these values increased significantly. A significant increase $(p<0.05)$ in $p$-AnV after 4 days of the test occurred in half of the examined samples, while $8^{\text {th }}$ day of the test an increase was significant in all samples except $\mathrm{H} 1$ and $\mathrm{H} 21$, where $p$-AnV did not change significantly even after 8 days of the test exposure. The results were summarized in Table 1.

The lowest PV and TOTOX in the initial sample, as well as after 4 and 8 days of the Schaal oven test were obtained in sample $\mathrm{H} 21$ and amounted to $0.36 \pm 0.01 \mathrm{mmol} \mathrm{kg}{ }^{-1}$, $2.37 \pm 0.29 \mathrm{mmol} \mathrm{kg}^{-1}, 4.85 \pm 0.17 \mathrm{mmol} \mathrm{kg}^{-1}$, respectively, and $1.12 \pm 0.02,2.99 \pm 0.38,7.39 \pm 1.55$, respectively (Table 1$)$. No significant difference was found between the sample $\mathrm{H} 21$ and the control RSO sample $(p<0.05)$ in the PV and TOTOX on the $4^{\text {th }}$ and $8^{\text {th }}$ day of the test. Kurhade $\&$ Waghmare (2014) tested the PV of refined sunflower oil on the $0^{\text {th }}, 4^{\text {th }}$, and $8^{\text {th }}$ day of the Schaal oven test and obtained the following values: $6.87 \pm 0.7$, $21.78 \pm 0.5$, and $45.56 \pm 0.23 \mathrm{meq} \mathrm{kg}^{-1}$, respectively. Differences in the mentioned values relative to the control sample in this paper (RSO) stem from differences in the fatty acid composition of the oils. Slightly lower TOTOX on the $0^{\text {th }}, 4^{\text {th }}$, and $8^{\text {th }}$ day of the test were determined in the H20 sample and amounted to $3.26 \pm 0.12,25.56 \pm 0.04$, and $62.69 \pm 0.05$, respectively. On the other hand, the average values of the examined samples were $6.31 \pm 3.07,57.53 \pm 17.14$ and $131.71 \pm 43.44$, respectively. $P$-AnV ranged from $0.05 \pm 0.02$ noticed $0^{\text {th }}$ day to $7.79 \pm 0.07$,

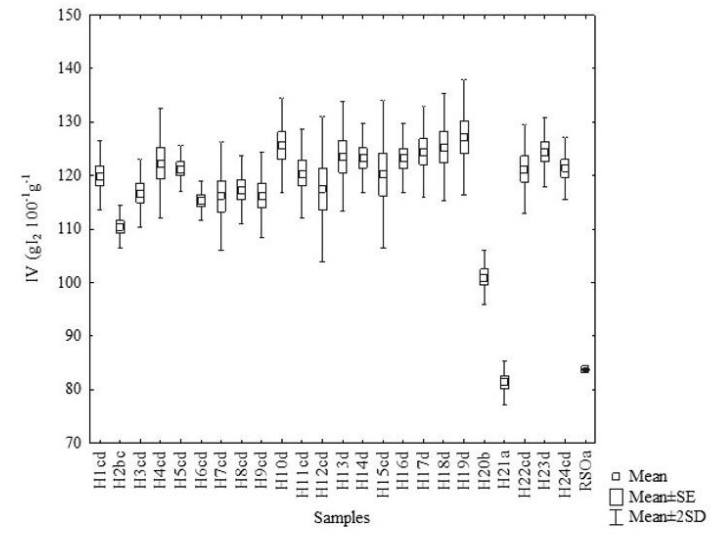

(a)

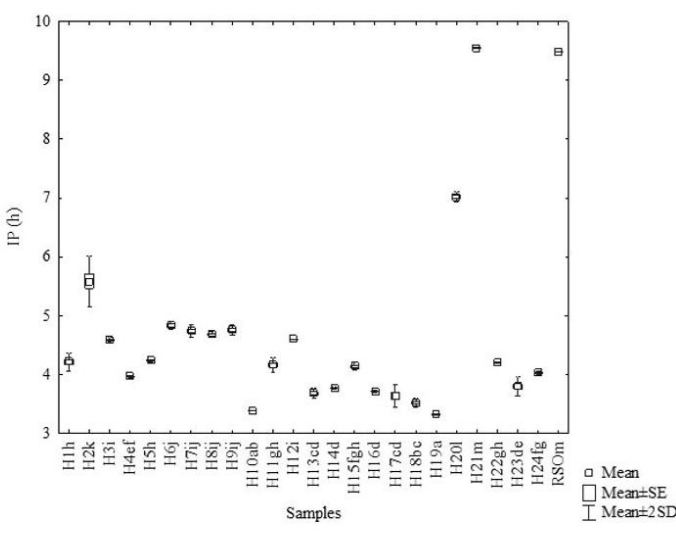

(b)

Figure 1. Box plot of the: (a) iodine value (IV) $\left[\mathrm{gI}_{2} 100^{-1} \mathrm{~g}^{-1}\right]$ and (b) induction period (IP) $[\mathrm{h}]$ of the tested oil samples. Different lower-case letters in the sample name indicate significantly different values between samples $(p<0.05)$. 
Table 1. Peroxide value (PV), $p$-anisidine value ( $p$-AnV), total oxidation value (TOTOX) in the initial samples and after 4 and 8 days of Schaal oven test.

\begin{tabular}{|c|c|c|c|c|c|c|c|c|c|}
\hline \multirow{2}{*}{ Hybrid } & \multicolumn{3}{|c|}{$\mathrm{PV}\left[\mathrm{mmol} \mathrm{kg}^{-1}\right]$} & \multicolumn{3}{|c|}{$p$-AnV } & \multicolumn{3}{|c|}{ TOTOX } \\
\hline & $0^{\text {th }}$ day & $4^{\text {th }}$ day & $8^{\text {th }}$ day & $0^{\text {th }}$ day & $4^{\text {th }}$ day & $8^{\text {th }}$ day & $0^{\text {th }}$ day & $4^{\text {th }}$ day & $8^{\text {th }}$ day \\
\hline $\mathrm{H} 1$ & $3.44 \pm 0.02^{\mathrm{mA}}$ & $24.88 \pm 2.45^{\mathrm{cdB}}$ & $56.33 \pm 4.89^{\text {cdefC }}$ & $1.19 \pm 0.29^{\mathrm{abcdA}}$ & $1.67 \pm 0.29^{\text {efghA }}$ & $2.16 \pm 0.58^{\text {defgh } A}$ & $8.07 \pm 0.31^{\mathrm{hA}}$ & $51.43 \pm 4.75^{\mathrm{deB}}$ & $114.82 \pm 10.09^{\mathrm{cdeC}}$ \\
\hline $\mathrm{H} 2$ & $1.85 \pm 0.02^{\mathrm{dA}}$ & $17.75 \pm 1.95^{\mathrm{bcB}}$ & $47.41 \pm 3.12^{\mathrm{cC}}$ & $0.23 \pm 0.02^{\mathrm{abA}}$ & $0.66 \pm 0.04^{\mathrm{abcA}}$ & $4.00 \pm 0.34^{\mathrm{klB}}$ & $3.94 \pm 0.01^{\mathrm{bcA}}$ & $36.16 \pm 3.94^{\mathrm{bcB}}$ & $98.82 \pm 5.90^{\mathrm{cC}}$ \\
\hline $\mathrm{H} 3$ & $2.45 \pm 0.03^{\mathrm{gA}}$ & $30.44 \pm 3.24^{\text {defghB }}$ & $65.19 \pm 4.42^{\text {defghic }}$ & $0.26 \pm 0.02^{\mathrm{abA}}$ & $0.69 \pm 0.04^{\mathrm{abcdB}}$ & $1.76 \pm 0.06^{\text {bdefgC }}$ & $5.17 \pm 0.07^{\text {defA }}$ & $61.57 \pm 6.52^{\operatorname{defgB}}$ & $132.14 \pm 8.78^{\mathrm{defgC}}$ \\
\hline $\mathrm{H} 4$ & $6.93 \pm 0.06^{\mathrm{rA}}$ & $36.99 \pm 4.67^{\text {ghijB }}$ & $76.39 \pm 6.24^{\mathrm{hiC}}$ & $1.27 \pm 0.07^{\mathrm{bcdA}}$ & $4.02 \pm 0.18^{\mathrm{kB}}$ & $4.60 \pm 0.20^{\mathrm{klC}}$ & $15.13 \pm 0.05^{\mathrm{kA}}$ & $78.00 \pm 9.16^{\mathrm{ijB}}$ & $157.38 \pm 12.68^{\mathrm{gC}}$ \\
\hline H5 & $1.74 \pm 0.01^{\mathrm{cdA}}$ & $25.86 \pm 1.59^{\mathrm{deB}}$ & $69.35 \pm 3.98^{\mathrm{fghiC}}$ & $0.07 \pm 0.04^{\mathrm{aA}}$ & $0.07 \pm 0.02^{\mathrm{aA}}$ & $1.72 \pm 0.20^{\mathrm{abcdefg} \mathrm{B}}$ & $3.55 \pm 0.04^{\mathrm{bA}}$ & $51.79 \pm 3.17^{\mathrm{deB}}$ & $140.42 \pm 8.16^{\mathrm{efg} C}$ \\
\hline $\mathrm{H} 6$ & $2.55 \pm 0.03^{\mathrm{ghA}}$ & $31.62 \pm 4.22^{\text {defghiB }}$ & $131.88 \pm 9.45^{j \mathrm{C}}$ & $0.05 \pm 0.02^{\mathrm{aA}}$ & $1.01 \pm 0.04^{\text {bcdefB }}$ & $3.59 \pm 0.20^{\mathrm{ijkC}}$ & $5.15 \pm 0.06^{\text {defA }}$ & $64.25 \pm 8.40^{\text {efghiB }}$ & $267.35 \pm 19.10^{\mathrm{hC}}$ \\
\hline H7 & $2.03 \pm 0.02^{\mathrm{eA}}$ & $24.07 \pm 1.87^{\mathrm{cdB}}$ & $59.45 \pm 3.24^{\text {cdefgC }}$ & $0.17 \pm 0.02^{\mathrm{abA}}$ & $2.58 \pm 0.10^{\mathrm{ijB}}$ & $4.10 \pm 0.85^{\mathrm{jkC}}$ & $4.23 \pm 0.06^{\mathrm{bcdA}}$ & $50.72 \pm 3.84^{\mathrm{cdeB}}$ & $123.00 \pm 7.33^{\text {cdefC }}$ \\
\hline $\mathrm{H} 8$ & $1.90 \pm 0.01^{\mathrm{deA}}$ & $27.45 \pm 3.24^{\mathrm{defB}}$ & $71.67 \pm 4.78^{\mathrm{ghiC}}$ & $0.09 \pm 0.02^{\mathrm{aA}}$ & $1.32 \pm 0.07^{\text {cdefgB }}$ & $2.29 \pm 0.14^{\text {efghC }}$ & $3.89 \pm 0.04^{\mathrm{bcA}}$ & $56.22 \pm 6.55^{\text {defgB }}$ & $145.63 \pm 9.70^{\mathrm{fgC}}$ \\
\hline H9 & $3.13 \pm 0.02^{1 \mathrm{~A}}$ & $37.51 \pm 5.23^{\mathrm{hijB}}$ & $70.93 \pm 7.82^{\text {ghic }}$ & $1.26 \pm 0.09^{\mathrm{bcdA}}$ & $2.29 \pm 0.51^{\mathrm{ijB}}$ & $7.79 \pm 0.07^{\mathrm{mC}}$ & $7.52 \pm 0.12^{\mathrm{hA}}$ & $77.31 \pm 10.73^{\text {hijB }}$ & $149.65 \pm 15.68^{\mathrm{fgC}}$ \\
\hline $\mathrm{H} 10$ & $3.98 \pm 0.05^{\circ \mathrm{A}}$ & $29.85 \pm 1.00^{\text {defgB }}$ & $54.70 \pm 4.10^{\mathrm{cdeC}}$ & $1.52 \pm 0.34^{\mathrm{cdA}}$ & $2.02 \pm 0.26^{\text {ghiA }}$ & $6.56 \pm 0.04^{\mathrm{mB}}$ & $9.48 \pm 0.31^{\mathrm{iA}}$ & $61.72 \pm 1.89^{\operatorname{defgB}}$ & $115.97 \pm 8.16^{\mathrm{cdeC}}$ \\
\hline H11 & $3.02 \pm 0.03^{\mathrm{klA}}$ & $28.08 \pm 1.03^{\mathrm{defB}}$ & $66.34 \pm 5.23^{\text {defghiC }}$ & $0.19 \pm 0.03^{\mathrm{abA}}$ & $0.33 \pm 0.02^{\mathrm{abB}}$ & $0.46 \pm 0.04^{\mathrm{aC}}$ & $6.24 \pm 0.03^{\mathrm{fgA}}$ & $56.49 \pm 2.03^{\text {defgB }}$ & $133.14 \pm 10.43^{\operatorname{defgC}}$ \\
\hline $\mathrm{H} 12$ & $3.67 \pm 0.02^{\mathrm{nA}}$ & $34.88 \pm 1.88^{\mathrm{fghijB}}$ & $70.90 \pm 5.03^{\mathrm{fghiC}}$ & $0.76 \pm 0.04^{\mathrm{abcA}}$ & $0.83 \pm 0.03^{\mathrm{bcdA}}$ & $2.32 \pm 0.12^{\text {ghiB }}$ & $8.10 \pm 0.08^{\mathrm{hA}}$ & $70.60 \pm 3.78^{\text {ghijB }}$ & $144.12 \pm 10.18^{\text {efgC }}$ \\
\hline $\mathrm{H} 13$ & $4.57 \pm 0.04^{\mathrm{pA}}$ & $26.05 \pm 2.10^{\mathrm{deB}}$ & $52.49 \pm 2.96^{\mathrm{cdC}}$ & $0.85 \pm 0.04^{\mathrm{abcA}}$ & $0.90 \pm 0.02^{\mathrm{bcdA}}$ & $1.02 \pm 0.02^{\mathrm{abcdeB}}$ & $9.99 \pm 0.04^{\mathrm{iA}}$ & $53.00 \pm 4.22^{\mathrm{defB}}$ & $106.00 \pm 5.94^{\mathrm{cdC}}$ \\
\hline H14 & $3.12 \pm 0.03^{1 \mathrm{~A}}$ & $28.55 \pm 1.66^{\text {defB }}$ & $63.25 \pm 4.04^{\text {defghiC }}$ & $0.68 \pm 0.03^{\mathrm{abcA}}$ & $0.89 \pm 0.02^{\mathrm{bcdB}}$ & $0.95 \pm 0.03^{\mathrm{abcdB}}$ & $6.92 \pm 0.08^{\mathrm{ghA}}$ & $57.99 \pm 3.29^{\text {defgB }}$ & $127.45 \pm 8.10^{\text {cdefC }}$ \\
\hline H15 & $1.79 \pm 0.03^{\mathrm{dA}}$ & $24.14 \pm 1.19^{\mathrm{cdB}}$ & $62.58 \pm 2.97^{\text {defghC }}$ & $0.53 \pm 0.03^{\mathrm{abcA}}$ & $0.66 \pm 0.04^{\mathrm{abcB}}$ & $0.78 \pm 0.04^{\mathrm{abcc}}$ & $4.11 \pm 0.08^{\mathrm{bcdA}}$ & $48.93 \pm 2.38^{\mathrm{cdB}}$ & $125.93 \pm 5.97^{\text {cdefC }}$ \\
\hline H16 & $2.80 \pm 0.05^{\mathrm{iA}}$ & $29.27 \pm 3.36^{\text {defB }}$ & $65.35 \pm 4.14^{\text {defghiC }}$ & $0.61 \pm 0.03^{\mathrm{abcA}}$ & $0.85 \pm 0.02^{\mathrm{bcdB}}$ & $1.03 \pm 0.03^{\text {abcdefC }}$ & $6.21 \pm 0.07^{\mathrm{fgA}}$ & $59.38 \pm 6.70^{\text {defgB }}$ & $131.72 \pm 8.25^{\operatorname{defg} C}$ \\
\hline H17 & $2.87 \pm 0.03^{3^{\mathrm{kA}}}$ & $31.13 \pm 1.33^{\text {defghB }}$ & $72.88 \pm 6.07^{\text {ghiC }}$ & $0.52 \pm 0.02^{\mathrm{abcA}}$ & $0.56 \pm 0.05^{\mathrm{abA}}$ & $1.60 \pm 0.02^{\text {abcdefgB }}$ & $6.27 \pm 0.03^{\mathrm{fgA}}$ & $62.82 \pm 2.62^{\text {defghB }}$ & $147.36 \pm 12.12^{\mathrm{fgC}}$ \\
\hline $\mathrm{H} 18$ & $2.20 \pm 0.02^{\mathrm{fA}}$ & $30.85 \pm 2.96^{\text {defghB }}$ & $67.56 \pm 5.45^{\text {efghiC }}$ & $0.47 \pm 0.06^{\mathrm{abcA}}$ & $0.83 \pm 0.03^{\mathrm{bcdA}}$ & $2.44 \pm 0.64^{\text {ghijB }}$ & $4.86 \pm 0.03^{\mathrm{cdeA}}$ & $62.53 \pm 5.93^{\text {defghB }}$ & $137.56 \pm 10.60^{\mathrm{efgC}}$ \\
\hline H19 & $2.60 \pm 0.09^{\mathrm{ghA}}$ & $33.28 \pm 0.61^{\text {efghijB }}$ & $77.26 \pm 4.20^{\mathrm{iC}}$ & $0.73 \pm 0.20^{\mathrm{abcA}}$ & $1.33 \pm 0.63^{\operatorname{cdefg} A}$ & $3.63 \pm 0.62^{\mathrm{jkB}}$ & $5.93 \pm 0.17^{\text {efgA }}$ & $67.88 \pm 1.50^{\text {fghijB }}$ & $158.15 \pm 9.02^{\mathrm{gC}}$ \\
\hline $\mathrm{H} 20$ & $1.59 \pm 0.06^{\mathrm{cA}}$ & $12.61 \pm 0.04^{\mathrm{bB}}$ & $30.32 \pm 0.03^{\mathrm{bC}}$ & $0.08 \pm 0.01^{\mathrm{aA}}$ & $0.35 \pm 0.05^{\mathrm{abB}}$ & $2.05 \pm 0.01^{\text {cdefghC }}$ & $3.26 \pm 0.12^{\mathrm{bA}}$ & $25.56 \pm 0.04^{\mathrm{bB}}$ & $62.69 \pm 0.05^{\mathrm{bC}}$ \\
\hline $\mathrm{H} 21$ & $0.36 \pm 0.01^{\mathrm{aA}}$ & $2.37 \pm 0.29^{\mathrm{aB}}$ & $4.85 \pm 0.17^{\mathrm{aC}}$ & $0.57 \pm 0.01^{\mathrm{abcA}}$ & $0.59 \pm 0.30^{\mathrm{abA}}$ & $0.65 \pm 0.43^{\mathrm{abA}}$ & $1.30 \pm 0.02^{\mathrm{aA}}$ & $5.33 \pm 0.30^{\mathrm{aB}}$ & $10.36 \pm 0.77^{\mathrm{aC}}$ \\
\hline $\mathrm{H} 22$ & $5.68 \pm 0.14^{\mathrm{qA}^{\mathrm{A}}}$ & $40.74 \pm 1.35^{\text {'в }}$ & $76.81 \pm 0.31^{\mathrm{hiC}}$ & $0.70 \pm 0.32^{\mathrm{abcA}}$ & $1.39 \pm 0.13^{\text {defghA }}$ & $4.04 \pm 0.87^{\mathrm{klB}}$ & $12.06 \pm 0.59^{j \mathrm{~A}}$ & $82.88 \pm 2.57^{\mathrm{jB}}$ & $157.66 \pm 1.48^{\mathrm{gC}}$ \\
\hline $\mathrm{H} 23$ & $2.67 \pm 0.03^{\text {hiA }}$ & $38.78 \pm 0.87^{\mathrm{ijB}}$ & $64.97 \pm 4.12^{\text {defghiC }}$ & $0.96 \pm 0.06^{\mathrm{abcA}}$ & $1.70 \pm 0.36^{\mathrm{fghA}}$ & $7.77 \pm 1.02^{\mathrm{mB}}$ & $6.31 \pm 0.10^{\mathrm{fgA}}$ & $79.26 \pm 1.38^{\mathrm{ijB}}$ & $137.71 \pm 9.26^{\mathrm{efgC}}$ \\
\hline $\mathrm{H} 24$ & $1.60 \pm 0.14^{\mathrm{cA}}$ & $28.94 \pm 0.44^{\mathrm{defB}}$ & $66.33 \pm 4.12^{\text {defghic }}$ & $0.65 \pm 0.01^{\mathrm{abcA}}$ & $0.95 \pm 0.02^{\text {bcdeA }}$ & $3.30 \pm 0.28^{\mathrm{hijkB}}$ & $3.85 \pm 0.28^{\mathrm{bcA}}$ & $58.83 \pm 0.89^{\operatorname{defg} B}$ & $135.96 \pm 8.38^{\text {efgC }}$ \\
\hline RSO & $1.12 \pm 0.02^{\mathrm{bA}}$ & $2.99 \pm 0.38^{\mathrm{aA}}$ & $7.39 \pm 1.55^{\mathrm{aB}}$ & $2.12 \pm 1.73^{\mathrm{dA}}$ & $2.88 \pm 0.43^{\mathrm{jAB}}$ & $5.02 \pm 0.11^{1 \mathrm{~B}}$ & $4.37 \pm 1.72^{\mathrm{bcdA}}$ & $8.86 \pm 0.35^{\mathrm{aA}}$ & $19.80 \pm 3.00^{\mathrm{aB}}$ \\
\hline
\end{tabular}

Values are means \pm standard deviation $(n=3)$. Different lower-case letters in the same column indicate significantly different values between samples while different upper-case letters in same raw indicate significantly different values of inidividual oxidative parameter ( $\mathrm{PV}, p$-AnV, TOTOX) between days during Schaal oven test $(p<0.05)$.

the highest value of the $8^{\text {th }}$ day of the test. The results obtained are consistent with the study reported by Romanić \& Kravić (2017).

The CD content ranged from $1.44 \pm 0.01$ ( $0^{\text {th }}$ day) to $21.28 \pm 0.01$ ( $8^{\text {th }}$ day of the test) as reported in Table 2 . The lowest CD value was also determined in sample $\mathrm{H} 21$. Obtained values are lower compared to results reported by Kiralan et al. (2008). Namely, CD content found in refined sunflower oil under Schaal oven test conditions after 8 days of the test was over 50 . RSO sample had 15 times lower CD value at the end of the test $(3.28 \pm 0.32)$ as a consequence of a lower degree of unsaturation (lower IV). The content of CT in tested samples ranged from $0.13 \pm 0.01$ $\left(0^{\text {th }}\right.$ day $)$ to $1.70 \pm 0.24\left(8^{\text {th }}\right)$.

The largest increase in PV, TOTOX, and CD were determined on $4^{\text {th }}$ day and averaged $9.86,9.11$, and 2.34 times. respectively. while after 8 days compared to the $4^{\text {th }}$ day of the test, this increase was lower and amounted to $2.29,2.29$ and 1.58 times, respectively. This significant difference $(p<0.05)$ between days during the Schaal oven test was also indicated by the different lower-case letters in Table 1 and Table 2. The greatest oxidative changes occurred in the first 4 days of the test. After $4^{\text {th }}$ day peroxides and conjugated dienes were formed but in lower quantities. The $p$-AnV and CT content increased on average 1.97 and 1.29 times on the $4^{\text {th }}$ day compared to initial samples, while after 8 days of the test compared to the $4^{\text {th }}$ day of test, the increasement was 2.48 and 1.48 times, respectively. Obtained values were expected since the $p$-AnV indicates secondary oxidation products are created later (Labuza \& Dugan, 1971), and CT are formed as oxidation products of fatty acids poorly present in sunflower oil (Takagi et al., 1987). Different values of oxidative characteristics during the Schaal oven test were a consequence of different degrees of unsaturation of samples (i.e. different fatty acid composition) but also different content and composition of bioactive components present in oils. Bioactive components will be the subject of further investigation. The obtained results were in line with previous studies (Wroniak et al.. 2016; Romanić \& Kravić, 2017).

Significant positive correlations $(p<0.01)$ were found between IV and PV, TOTOX, and CD during the Schaal oven test (Table 3.). The obtained correlations were in accordance with the previous researches and were expected because, with the increase of the IV the oxidative stability of the oil decreases, i.e. oxidative parameter values also increase (Knothe, 2002; Moser, 2008; Moser, 2011). The TOTOX gives a comprehensive picture indicating both primary and secondary oxidation products (Saeed \& Naz, 2019; Patsioura et al., 2017). The secondary oxidation products content shown as the $p$-AnV did not have a statistically significant correlation with the IV, explained by the low content of secondary oxidation products during the 8 days of the Schaal oven test, so this correlation would be better in the case of longer exposure to the test conditions. No statistically significant correlation was found between CT and IV. The reason was, as mentioned, the low content of fatty acids necessary to form conjugated trienes in oxidation processes. 
Table 2. Conjugated dienes (CD) and conjugated trienes (CT) content in the initial samples and after 4 and 8 days of Schaal oven test.

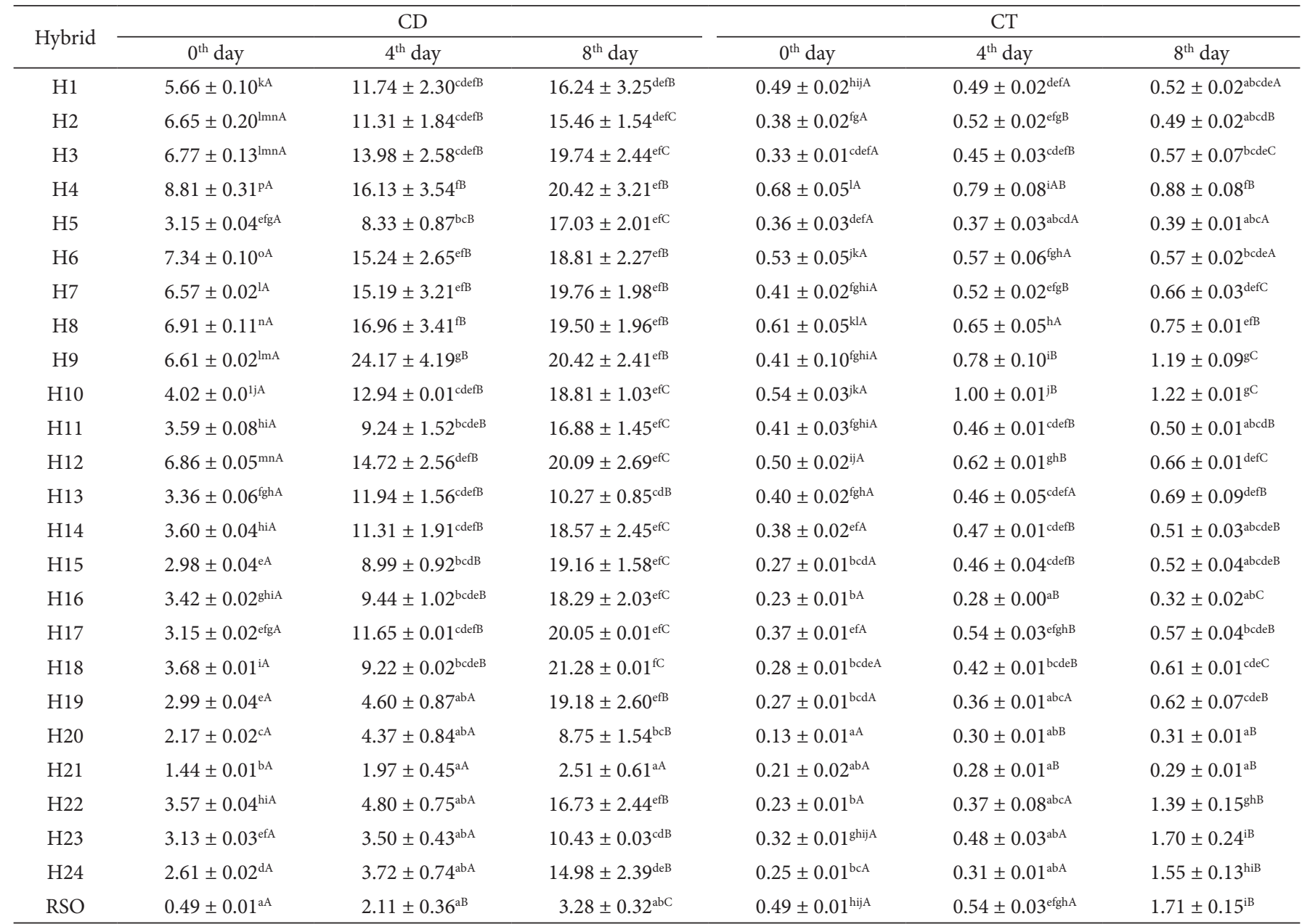

Values are means \pm standard deviation $(n=3)$. Different lower-case letters in the same column indicate significantly different values between samples while different upper-case letters in same raw indicate significantly different values of inidividual oxidative parameter ( $\mathrm{PV}, p$-AnV, TOTOX) between days during Schaal oven test $(p<0.05)$.

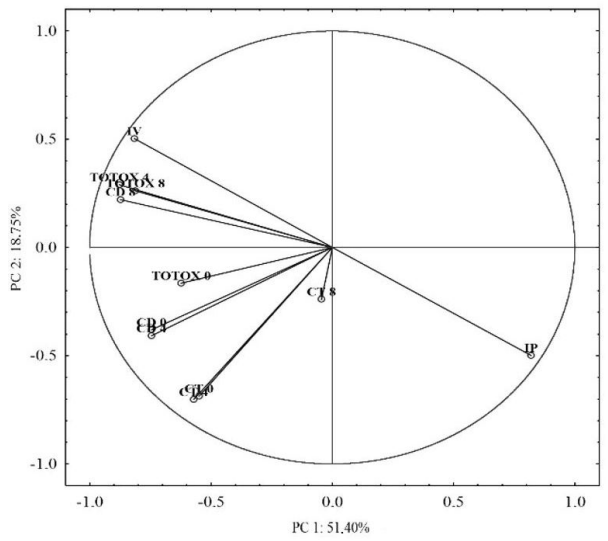

(a)

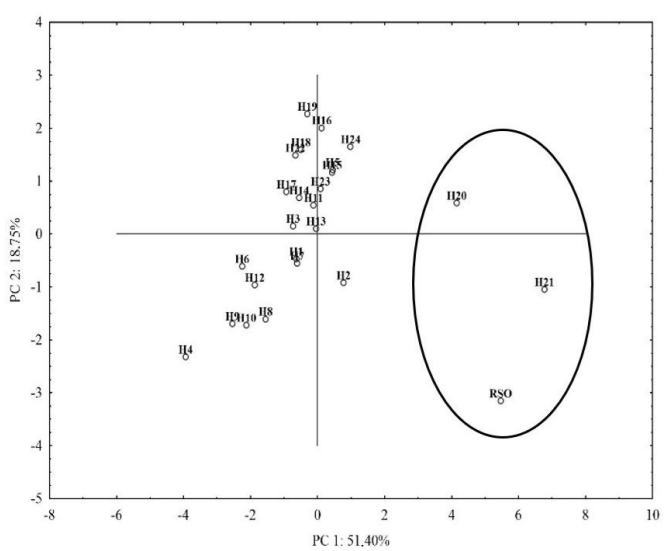

(b)

Figure 2. PCA analysis: (a) Loading plot of PC1-PC2 for different sunflower cold-pressed oils and refined sunflower oil (TOTOX-total oxidation value, CD-conjugated dienes and CT-conjugated trienes during Schaal oven test $\left(0^{\text {th }}, 4^{\text {th }}\right.$ and $8^{\text {th }}$ day), IV-iodine value, IP-induction period); (b) Score plot of PC1-PC2 for different sunflower cold-pressed oils and refined sunflower oil.

The IP indicates the resistance of the sample to oxidative changes and correlations of induction period with oxidative parameters $(\mathrm{PV}, \mathrm{TOTOX}$, and CD) are significantly negative $(p<0.01)$ which correlated well with values reported previously (Ghosh et al., 2019; Li et al., 2019). Symoniuk et al. (2018) examined the correlation of IP and TOTOX of 27 different cold-pressed oil samples (linseed, 
Table 3. Correlations of the iodine value (IV) and induction period (IP) with oxidation products content (peroxide value (PV), $p$-Anisidine value $(p-\mathrm{AnV})$, total oxidation value (TOTOX), conjugated dienes content (CD) and conjugated trienes content (CT)) during Schaal oven test.

\begin{tabular}{|c|c|c|c|}
\hline \multicolumn{2}{|c|}{ Parameter } & IV & IP \\
\hline \multicolumn{2}{|c|}{ IP } & $-0.96^{* *}$ & $1^{\star *}$ \\
\hline \multirow{3}{*}{ PV } & $0^{\text {th }}$ day & $0.51^{\star *}$ & $-0.52^{\star *}$ \\
\hline & $4^{\text {th }}$ day & $0.80^{\star *}$ & $-0.83^{\star *}$ \\
\hline & $8^{\text {th }}$ day & $0.67^{\star *}$ & $-0.69^{* *}$ \\
\hline \multirow{3}{*}{$p-A n V$} & $0^{\text {th }}$ day & -0.14 & 0.15 \\
\hline & $4^{\text {th }}$ day & -0.05 & 0.06 \\
\hline & $8^{\text {th }}$ day & 0.04 & -0.03 \\
\hline \multirow{3}{*}{ TOTOX } & $0^{\text {th }}$ day & $0.44^{\star *}$ & $-0.46^{\star *}$ \\
\hline & $4^{\text {th }}$ day & $0.80^{\star *}$ & $-0.83^{\star *}$ \\
\hline & $8^{\text {th }}$ day & $0.67^{\star *}$ & $-0.70^{\star *}$ \\
\hline \multirow{3}{*}{$\mathrm{CD}$} & $0^{\text {th }}$ day & $0.31^{\star}$ & $-0.34^{\star}$ \\
\hline & $4^{\text {th }}$ day & $0.32^{*}$ & $-0.36^{*}$ \\
\hline & $8^{\text {th }}$ day & $0.72^{\star \star}$ & $-0.75^{\star *}$ \\
\hline \multirow{3}{*}{$\mathrm{CT}$} & $0^{\text {th }}$ day & 0.16 & -0.16 \\
\hline & $4^{\text {th }}$ day & 0.14 & -0.16 \\
\hline & $8^{\text {th }}$ day & 0.00 & 0.03 \\
\hline
\end{tabular}

*statistically significant at $p<0.01$; ${ }^{* *}$ statistically significant at $p<0.001$.

rapeseed, camelina, black cumin, evening primrose, hempseed, milk thistle, poppy, pumpkin, and sunflower) and obtained significant $(p<0.05)$ negative correlations between the IP and PV and TOTOX, while no significant correlation was found with the $p-A n V$.

\subsection{PCA}

Relations between the oxidative parameters obtained by accelerated stability tests (TOTOX, CD, CT, IP) and IV were analyzed. The PCA was applied to study the relationships between selected variables and derive new principal components (PCs) where these variables can be classified. The PCA was also used to map the samples tested in our experiment (24 samples of different cold-pressed sunflower oils and refined sunflower oil as control) into these new components. The PCA showed that the first two PCs were the most important elements explaining variation in the data; they accounted for approximately $70.15 \%$ of the total variance $(51.40 \%$ and $18.75 \%$, respectively). The IP has a positive effect on PC1, while IV, CD content $0^{\text {th }}, 4^{\text {th }}$, and $8^{\text {th }}$ day, as well as TOTOX $4^{\text {th }}$ and $8^{\text {th }}$ day of the Schaal oven test, have the greatest negative effect (Figure 2a). PC1 seems to indicate oxidative stability, i.e. the ability of samples to resist oxidative changes. IV had the highest positive effect on PC2, while CT on $0^{\text {th }}$ and $4^{\text {th }}$ day of the Schaal oven test, as well as the IP, had the greatest negative, and PC2 takes into account the influence of the degree of fatty acid unsaturation on the oxidative changes of the samples under accelerated stability test conditions. Figure $2 \mathrm{~b}$ shows clear segregation of $\mathrm{H} 20, \mathrm{H} 21$, and RSO samples which indicates significantly better oxidative characteristics compared to other tested samples, due to the lower degree of fatty acid unsaturation. Similar results were obtained by Redondo-Cuevas et al. (2018). They applied PCA to oil samples originating from different raw materials (corn, olive, sunflower, rapeseed, sesame, coconut, palm, butter, ghee) and obtained new PCs accounting for $66.6 \%$ of the total variance (PC1 accounts for $46.3 \%$ and PC2 20.3\%). High oleic sunflower oil belonged to the olive oils group confirming their similar oxidative behavior.

\section{Conclusion}

New sunflower hybrids with improved characteristics are created permanently. Present sunflower hybrids will be replaced by new ones and oil producers will need guidance in the selection of new hybrids. Their main concern is how to produce good quality oil with the longest possible shelf life, therefore, in this paper, the oxidative characteristics of new cold pressed sunflower oils during accelerated thermal stability tests were examined. The best oxidative characteristics were shown by the sample $\mathrm{H} 21$, the most similar to the control (RSO) sample. The TOTOX of this sample was $1.30 \pm 0.02\left(0^{\text {th }}\right.$ day), while on the 8 th day of the test was $10.36 \pm 0.77$. This sample also had the largest IP of $9.55 \pm 0.00 \mathrm{~h}$, as well as the lowest IV $\left(81 \pm 2.04 \mathrm{gI}_{2} 100^{-1} \mathrm{~g}^{-1}\right)$. PCA mapped and isolated samples $\mathrm{H} 21, \mathrm{H} 20$, and control RSO, as the most oxidatively stable oils. In addition, this work proved the possibility of production of oxidatively stable oils from the confectionary sunflower hybrid seeds, not previously used for this purpose.

\section{Acknowledgment}

This research is financed by the Ministry of Education, Science and Technology Development of the Republic of Serbia, Project Number 451-03-68/2020-14/200134.

\section{References}

Akkaya, M. (2018). Fatty acid compositions of sunflowers (Helianthus annuus L.) grown in east mediterranean region. Rivista Italiana delle Sostanze Grasse, 95, 239-247. 
Choe, E., \& Min, D. B. (2006). Mechanisms and factors for edible oil oxidation. Comprehensive Reviews in Food Science and Food Safety, 5(4), 169-186. http://dx.doi.org/10.1111/j.1541-4337.2006.00009.x.

Codex Committee on Fats and Oils. (2005). Codex Stan 210-1999. Codex standard for named vegetable oils. Rome: Joint FAO/WHO Food Standards Programme.

de Lira, L. F. B., de Albuquerque, M. S., Pacheco, J. G. A., Fonseca, T. M., Cavalcanti, E. H. S., Stragevitch, L., \& Pimentel, M. F. (2010). Infrared spectroscopy and multivariate calibration to monitor stability quality parameters of biodiesel. Microchemical Journal, 96(1), 126-131. http://dx.doi.org/10.1016/j.microc.2010.02.014.

Dobarganes, M. C., \& Velasco, J. (2002). Analysis of lipid hydroperoxides. European Journal of Lipid Science and Technology, 104(7), 420-428. http://dx.doi.org/10.1002/1438-9312(200207)104:7<420::AIDEJLT420>3.0.CO;2-N.

Ferrari, R. A., \& Souza, W. L. (2009). Avaliação da estabilidade oxidativa de biodiesel de óleo de girassol com antioxidantes (Evaluation of oxidative stability of sunflower oil biodiesel with antioxidants). Quimica Nova, 32(1), 106-111. http://dx.doi.org/10.1590/S010040422009000100020.

Ghosh, M., Upadhyay, R., Mahato, D., \& Mishra, H. (2019). Kinetics of lipid oxidation in omega fatty acids rich blends of sunflower and sesame oils using Rancimat. Food Chemistry, 272, 471-477. http:// dx.doi.org/10.1016/j.foodchem.2018.08.072. PMid:30309570.

Gomes, T., Caponio, F., Bruno, G., Summo, C., \& Paradiso, V. (2010). Effects of monoacylglycerols on the oxidative stability of olive oil. Journal of the Science of Food and Agriculture, 90(13), 2228-2232. http://dx.doi.org/10.1002/jsfa.4075. PMid:20632384.

González-Díaz, H., Saíz-Urra, L., Molina, R., González-Díaz, Y., \& Sánchez-González, A. (2007). Computational chemistry approach to protein kinase recognition using 3D stochastic van der Waals spectral moments. Journal of Computational Chemistry, 28(6), 1042-1048. http://dx.doi.org/10.1002/jcc.20649. PMid:17269125.

Górnaś, P., Rudzińska, M., \& Soliven, A. (2017). Industrial by-products of plum Prunus domestica L. and Prunus cerasifera Ehrh. as potential biodiesel feedstock: impact of variety. Industrial Crops and Products, 100, 77-84. http://dx.doi.org/10.1016/j.indcrop.2017.02.014.

Górnaś, P., Siger, A., Juhņeviča, K., Lācis, G., Šnē, E., \& Seglina, D. (2014). Cold-pressed Japanese quince (Chaenomeles japonica (Thunb.) Lindl. Ex Spach) seed oil as a rich source of a-tocopherol, carotenoids and phenolics: a comparison of the composition and antioxidant activity with nine other plant oils. European Journal of Lipid Science and Technology, 116(5), 563-570. http://dx.doi. org/10.1002/ejlt.201300425.

Hashemi, S., Khaneghah, A., Tavakolpour, Y., Asnaashari, M., \& Mehr, H. (2015). Effects of ultrasound treatment, UV irradiation and avishan-e-denaei essential oil on oxidative stability of sunflower oil. Journal of Essential Oil-Bearing Plants, 18(5), 1083-1092. http:// dx.doi.org/10.1080/0972060X.2015.1039218.

International Organization for Standardization - ISO. (2017a). ISO 3656:2013/Amd 1:2017. Animal and vegetable fats and oils Determination of ultraviolet absorbance expressed as specific UV extinction - Amendment 1. Geneva: ISO.

International Organization for Standardization - ISO. (2017b). ISO 3960:2017. Animal and vegetable fats and oils - Determination of peroxide value - Iodometric (visual) endpoint determination. Geneva: ISO.

International Organization for Standardization - ISO. (2018). ISO 3961:2018. Animal and vegetable fats and oils - Determination of iodine value. Geneva: ISO.
International Organization for Standardization - ISO. (2016a). ISO 6885:2016. Animal and vegetable fats and oils - Determination of anisidine value. Geneva: ISO.

International Organization for Standardization - ISO. (2016b). ISO 6886:2016. Animal and vegetable fats and oils - Determination of oxidative stability (accelerated oxidation test). Geneva: ISO.

Kiralan, M., Bayrak, A., \& Çalikoglu, E. (2008). Effect of nigella seed extract on oxidative stability of refined sunflower oil. Asian Journal of Chemistry, 20, 3313-3318.

Knothe, G. (2002). Structure indices in FA chemistry. How relevant is the iodine value? Journal of the American Oil Chemists' Society, 79(9), 847-854. http://dx.doi.org/10.1007/s11746-002-0569-4.

Konuskan, D., Arslan, M., \& Oksuz, A. (2019). Physicochemical properties of cold pressed sunflower, peanut, rapeseed, mustard and olive oils grown in the Eastern Mediterranean region. Saudi Journal of Biological Sciences, 26(2), 340-344. http://dx.doi.org/10.1016/j. sjbs.2018.04.005. PMid:31485174.

Kovačević, S., Podunavac Kuzmanović, S., \& Jevrić, L. (2013). Multivariate regression modelling of antifungal activity of some benzoxazole and oxazolo[4,5-B]pyridine derivatives. Acta Chimica Slovenica, 60, 756-762.

Kurhade, A., \& Waghmare, J. (2014). Effect of banana peel oleoresin on oxidative stability of sunflower and soybean oil. Journal of Food Processing and Preservation, 39(6), 1788-1797. http://dx.doi. org/10.1111/jfpp.12413.

Labuza, T. P., \& Dugan, L. R. (1971). Kinetics of lipid oxidation in foods. CRC Critical Reviews in Food Technology, 2, 355-405. http://dx.doi. org/10.1080/10408397109527127.

Landers, R. E., \& Rathmann, D. M. (1981). Vegetable oils: effects of processing, storage and use on nutritional values. Journal of the American Oil Chemists' Society, 58(3 Pt 1), 255-259. http://dx.doi. org/10.1007/BF02582352.

Leong, X. F., Ng, C. Y., Jaarin, K., \& Mustafa, M. R. (2015). Effects of repeated heating of cooking oils on antioxidant content and endothelial function. Austin Journal of Pharmacology and Therapeutics, 3, 1-7.

Li, X., Li, Y., Yang, F., Liu, R., Zhao, C., Jin, Q., \& Wang, X. (2019). Oxidation degree of soybean oil at induction time point under Rancimat test condition: theoretical derivation and experimental observation. Food Research International, 120, 756-762. http://dx.doi. org/10.1016/j.foodres.2018.11.036. PMid:31000295.

Marmesat, S., Morales, A., Velasco, J., Ruiz-Méndez, M., \& Dobarganes, M. (2009). Relationship between changes in peroxide value and conjugated dienes during oxidation of sunflower oils with different degree of unsaturation. Grasas y Aceites, 60(2), 155-160. http:// dx.doi.org/10.3989/gya.096908.

Maszewska, M., Florowska, A., Dłuzewska, E., Wroniak, M., MarciniakLukasiak, K., \& Zbikowska, A. (2018). Oxidative stability of selected edible oils. Molecules (Basel, Switzerland), 23(7), 1746. http://dx.doi. org/10.3390/molecules23071746. PMid:30018226.

Moser, B. R. (2008). Influence of blending canola, palm, soybean, and sunflower oil methyl esters on fuel properties of biodiesel. Energy \& Fuels, 22(6), 4301-4306. http://dx.doi.org/10.1021/ef800588x.

Moser, B. R. (2011). Influence of extended storage on fuel properties of methyl esters prepared from canola, palm, soybean and sunflower oils. Renewable Energy, 36(4), 1221-1226. http://dx.doi.org/10.1016/j. renene.2010.10.009.

Naderi, M., Farmani, J., \& Rashidi, L. (2018). The impact of saturated monoacylglycerols on the oxidative stability of Canola oil under various time/temperature conditions. Grasas y Aceites, 69(3), 267. http://dx.doi.org/10.3989/gya.0346181. 
Oomah, B., Ladet, S., Godfrey, D., Liang, J., \& Girard, B. (2000). Characteristics of raspberry (Rubus idaeus L.) seed oil. Food Chemistry, 69(2), 187-193. http://dx.doi.org/10.1016/S0308-8146(99)00260-5.

Patsioura, A., Ziaiifar, A., Smith, P., Menzel, A., \& Vitrac, O. (2017). Effects of oxygenation and process conditions on thermo-oxidation of oil during deep-frying. Food and Bioproducts Processing, 101, 84-99. http://dx.doi.org/10.1016/j.fbp.2016.10.009.

Popescu, R., Costinel, D., Dinca, O., Marinescu, A., Stefanescu, I., \& Ionete, R. (2015). Discrimination of vegetable oils using NMR spectroscopy and chemometrics. Food Control, 48, 84-90. http:// dx.doi.org/10.1016/j.foodcont.2014.04.046.

Redondo-Cuevas, L., Castellano, G., Torrens, F., \& Raikos, V. (2018). Revealing the relationship between vegetable oil composition and oxidative stability: a multifactorial approach. Journal of Food Composition and Analysis, 66, 221-229. http://dx.doi.org/10.1016/j.jfca.2017.12.027.

Romanić, R., \& Kravić, S. (2017). Investigation of the oxidative stability of cold pressed sunflower oil of high-oleic type subjected to elevated temperature. Hemijska Industrija, 71(2), 175-182. http://dx.doi. org/10.2298/HEMIND160301022R.

Saeed, R., \& Naz, S. (2019). Effect of heating on the oxidative stability of corn oil and soybean oil. Grasas y Aceites, 70(2), 303. http://dx.doi. org/10.3989/gya.0698181.

Salas, J. J., Bootello, M. A., Martínez-Force, E., \& Garcés, R. (2011). Production of stearate-rich butters by solvent fractionation of high stearic-high oleic sunflower oil. Food Chemistry, 124(2), 450-458. http://dx.doi.org/10.1016/j.foodchem.2010.06.053.
Salas, J., Bootello, M., \& Garcés, R. (2015). Food uses of sunflower oils. In E. Martínez-Force, N. Turgut Dunford, \& J. J. Salas (Eds.), Sunflower chemistry, production, processing, and utilization (pp. 441464). Urbana, Ilinois, USA: AOCS Press. http://dx.doi.org/10.1016/ B978-1-893997-94-3.50020-9.

Serrano-Vega, M. J., Martínez-Force, E., \& Garcés, R. (2005). Lipid characterization of seed oils from high-palmitic, low-palmitoleic, and very high-stearic acid sunflower lines. Lipids, 40(4), 369-374. http://dx.doi.org/10.1007/s11745-006-1396-y. PMid:16028719.

Symoniuk, E., Ratusz, K., Ostrowska-Ligęza, E., \& Krygier, K. (2018). Impact of selected chemical characteristics of cold-pressed oils on their oxidative stability determined using the rancimat and pressure differential scanning calorimetry method. Food Analytical Methods, 11(4), 1095-1104. http://dx.doi.org/10.1007/s12161-017-1081-1.

Szterk, A., Roszko, M., Sosińska, E., Derewiaka, D., \& Lewicki, P. P. (2010). Chemical composition and oxidative stability of selected plant oils. Journal of the American Oil Chemists' Society, 87(6), 637645. http://dx.doi.org/10.1007/s11746-009-1539-4.

Takagi, T., Wakasa, N., \& Miyashita, K. (1987). Formation of conjugated diene and triene products in lipoxygenase oxidation of C18, C20, C22 PUFAs. Journal of the American Oil Chemists' Society, 64(9), 1320-1323. http://dx.doi.org/10.1007/BF02540790.

Wroniak, M., Florowska, A., \& Rekas, A. (2016). Effect of oil flushing with nitrogen on the quality and oxidative stability of cold-pressed rapeseed and sunflower oils. Acta Scientiarum Polonorum. Technologia Alimentaria, 15(1), 79-87. http://dx.doi.org/10.17306/J.AFS.2016.1.8. PMid:28071041. 